Check for updates

Cite this: RSC Adv., 2018, 8, 27654

\title{
Preparation and application synthesis of magnetic nanocomposite using waste toner for the removal of $\mathrm{Cr}(\mathrm{vi}) \dagger$
}

\author{
Hong Zhu, ${ }^{a}$ Yucheng Zhou, ${ }^{a}$ Shengsen Wang, ${ }^{\text {ab }}$ Xiaoge Wu, ${ }^{a}$ Jianhua Hou, ${ }^{\text {ab }}$ \\ Weiqin Yin, ${ }^{a}$ Ke Feng, ${ }^{\text {ab }}$ Xiaozhi Wang (D) ${ }^{* a b c}$ and Jie Yang ${ }^{d}$
}

In this study, a novel magnetic nanocomposite was prepared using waste toner (WT) through high temperature decomposition, and calcination was conducted in different atmospheres (air, ammonia, and vacuum). WT calcined in ammonia (WT( $\left(\mathrm{NH}_{3}\right)$ ), and it was then utilized as an efficient absorbent for the reduction of $\mathrm{Cr}(\mathrm{VI})$ in aqueous solutions; a batch experiment with different conditions was performed to investigate its $\mathrm{Cr}(\mathrm{VI})$ removal ability. The effects of two $\mathrm{pH}$-regulating acid $\left(\mathrm{HCl}\right.$ and $\left.\mathrm{H}_{2} \mathrm{SO}_{4}\right)$ treatments were also studied. It was found that $\mathrm{WT}\left(\mathrm{NH}_{3}\right)$ could remove about $99 \% \mathrm{Cr}(\mathrm{vI})$ at $\mathrm{pH} 2$ under $\mathrm{H}_{2} \mathrm{SO}_{4}$ treatment. The XRD and TEM results coupled with VSM results confirmed that WT(NH3) is an $\mathrm{Fe}_{3} \mathrm{O}_{4} / \mathrm{Fe}_{2} \mathrm{~N}$ nanohybrid, which possesses excellent water-dispersibility and remarkable magnetic properties. XPS analysis showed the presence of $\mathrm{Cr}(\mathrm{VI})$ and $\mathrm{Cr}(\mathrm{III})$ on the surface of $\mathrm{WT}\left(\mathrm{NH}_{3}\right)$, which indicated that $\mathrm{Cr}(\mathrm{VI})$ was reduced to $\mathrm{Cr}(\mathrm{III})$. Furthermore, $\mathrm{H}_{2} \mathrm{SO}_{4}$ regulation also promoted the reduction of $\mathrm{Cr}(\mathrm{VI})$ by WT( $\left.\mathrm{NH}_{3}\right)$,

and this reduction was higher than that obtained by $\mathrm{HCl}$ regulation.

Received 20th June 2018

Accepted 18th July 2018

DOI: $10.1039 / c 8 r a 05291 c$

rsc.li/rsc-advances

\section{Introduction}

Chromium (Cr) is a very common and toxic heavy metal, and it is usually present in water and soil. Most $\mathrm{Cr}$ in the environment is released from industrial activities including tanning, textile preservation, electroplating, and sewage sludge. ${ }^{1,2}$ The hazards of chromium to the human body mainly include skin and respiratory ulcers, meningitis, and lung cancer. ${ }^{3}$ Thus, the US Environmental Protection Agency has recommended that the $\mathrm{Cr}$ concentration should be below $50 \mu \mathrm{g} \mathrm{L}{ }^{-1}$ (ref. 4) in most natural waters. $\mathrm{Cr}$ is most frequently present in the hexavalent $(\mathrm{Cr}(\mathrm{VI}))$ or trivalent $(\mathrm{Cr}(\mathrm{III}))$ forms in aqueous solutions. ${ }^{5}$ These two common oxidation states of $\mathrm{Cr}$ are extremely different in charge, physicochemical properties and chemical and biochemical reactivities. ${ }^{6}$ In fact, the toxicity of $\mathrm{Cr}(\mathrm{vr})$ is five hundred times greater than that of $\mathrm{Cr}(\mathrm{III}) .^{7} \mathrm{Cr}(\mathrm{VI})$ ions exist as chromate ions $\left(\mathrm{CrO}_{4}{ }^{2-}\right)$ and dichromate ions $\left(\mathrm{Cr}_{2} \mathrm{O}_{7}{ }^{2-}\right)$ in solution, and these ions are more soluble and mobile than $\mathrm{Cr}(\mathrm{vI})$ in ground water; they are also more capable of oxidizing other species. ${ }^{8}$ Therefore, several

${ }^{a}$ College of Environmental Science and Engineering, Yangzhou University, Jiangsu 225127, China.E-mail: xzwang@yzu.edu.cn

${ }^{b}$ Jiangsu Collaborative Innovation Center for Solid Organic Waste Resource Utilization, Nanjing 210095, China

'Institutes of Agricultural Science and Technology Development, Yangzhou University, Yangzhou 225127, Jiangsu, China

${ }^{d}$ Key Laboratory of Crop and Livestock Integration, Ministry of Agriculture, Nanjing 210095, China

$\dagger$ Electronic supplementary information (ESI) available. See DOI: $10.1039 / \mathrm{c} 8 \mathrm{ra} 05291 \mathrm{c}$ treatment methods have been applied such as ion exchange, electrolytic removal, chemical precipitation, ${ }^{9}$ adsorption, ${ }^{10}$ and reduction. ${ }^{11}$ Recently, reduction-sorption has been considered as an efficient and economically viable method for $\mathrm{Cr}(\mathrm{vI})$ removal. Moreover, $\mathrm{Cr}(\mathrm{vI})$ can be reduced to its less toxic form. ${ }^{12}$ However, this method requires absorbents that contain abundant active sites or functional groups.

With the increasing demand for electronic and electrical equipment (EEE) in modern society, a significant amount of EEE waste (WEEE) is produced, and the major constituents of WEEE plastics include polypropylene (PP) and high-impact polystyrene (HIPS).$^{13}$ To recycle WEEE, some researchers have prepared R-PP/R-HIPS blends by adding polystyrenepoly(ethylene/propylene) (SEP) or glycidyl methacrylate (GMA) to obtain functional polymer nanocomposites. ${ }^{14}$ Also, it has been reported that near-critical water can be used to recycle printed circuit boards for the collection of copper foils and fabrics..$^{15}$ The overuse of printing equipment has led to a significant increase in the number of waste toner cartridges. ${ }^{16}$ Powdery waste toner (WT) accounts for $8.0 \mathrm{wt} \%$ of a toner cartridge. Also, the weight of WT has reached about $36 \mathrm{t}$ per year in China. Furthermore, if WT is disposed without reasonable management, its toxic components, including hazardous organic components, will be released into the environment, which can pollute the soil, underground water and air; this will be a tremendous threat to the human health. ${ }^{17}$ In fact, WT is a mixture that includes about $7.0 \mathrm{wt} \%$ polyacrylate, $55.0 \mathrm{wt} \%$ polystyrene, $3.0 \mathrm{wt} \% \mathrm{SiO}_{2}$, and $35.0 \mathrm{wt} \% \mathrm{Fe}_{3} \mathrm{O}_{4} \cdot{ }^{18-20}$ In recent years, very few researchers have studied the recycling and 
transformation of WT. The method of vacuum-gasificationcondensation was used to treat WT since the organic matter in WT can be decomposed and gasified at high temperature. Meanwhile, $\mathrm{SiO}_{2}$ and $\mathrm{Fe}_{3} \mathrm{O}_{4}$ in WT were transformed into nanosized $\mathrm{Fe}_{3} \mathrm{O}_{4}$ and nano- $\mathrm{SiO}_{2} \cdot{ }^{19} \mathrm{~A}$ thermal transformation process was investigated to convert WT into $98 \%$ pure iron by using the gases collected during the thermal transformation as an in situ source of carbon. ${ }^{21}$

Recently, iron-bearing materials have been applied to various fields such as drug delivery, sensors, electromagnetic interference shielding, and adsorbents for environmental remediation..$^{22-24}$ In the environmental field, iron-bearing materials such as magnetite,,$^{25,26}$ iron sulfides, ${ }^{27,28}$ goethite, ${ }^{29}$ and zerovalent iron $^{30}$ can remediate $\mathrm{Cr}(\mathrm{vI})$. It has also been reported that fabric- and cellulose-derived magnetic carbon-iron nanomaterials possess high efficiency for $\mathrm{Cr}(\mathrm{vI})$ removal, ${ }^{31,32}$ where $\mathrm{Cr}(\mathrm{VI})$ is reduced to $\mathrm{Cr}(\mathrm{III})$ by the reductive intermediates generated from ZVI such as Fe(II). Moreover, the nanocarbon structure and different carbonization temperatures affect the $\mathrm{Cr}(\mathrm{vI})$ removal capacity. ${ }^{33,34}$ Also, $\mathrm{Fe}_{3} \mathrm{O}_{4}$ is a type of iron oxide, and it exhibits remarkable performance owing to its high efficiency of adsorbing $\operatorname{Cr}(\mathrm{vI})$ and reducing $\mathrm{Cr}(\mathrm{vI})$ to less toxic $\mathrm{Cr}(\mathrm{III}){ }_{.}^{35}$ Furthermore, compared to traditional absorbents, this compound can be separated and recovered rapidly using an external magnetic field. It is known that $\mathrm{Fe}_{3} \mathrm{O}_{4}$ nanoparticles can be obtained by calcining WT. Although the calcination of WT has been previously studied, its calcination under different atmospheres and $\mathrm{Cr}(\mathrm{vr})$ uptake using the resultant nanoparticles have not been well investigated.

In this study, we attempted to develop a novel low-cost magnetic nanocomposite by recycling waste toner through high-temperature decomposition. Calcination was conducted in air, ammonia and vacuum to explore the influence of atmosphere on WT modification. Due to the unique properties of the materials, we used different acids to adjust the $\mathrm{pH}$ value during the experiments, and the results showed significant difference. The aim of this study is to characterize the as-prepared WTs, evaluate their applicability for $\mathrm{Cr}(\mathrm{vI})$ adsorption and reduction, and explore the mechanisms of $\mathrm{Cr}(\mathrm{vI})$ removal.

\section{Materials and methods}

\subsection{Reagents}

$\mathrm{Cr}(\mathrm{vI})$ aqueous solution was prepared by dissolving potassium dichromate $\left(\mathrm{K}_{2} \mathrm{Cr}_{2} \mathrm{O}_{7}\right)$. pH adjustment was carried out using $0.1 \mathrm{M} \mathrm{HCl}, 1.1 \mathrm{M} \mathrm{H}_{2} \mathrm{SO}_{4}$ and $0.1 \mathrm{M} \mathrm{NaOH}$. All the reagents were of analytical grade and purchased from the Sinopharm Chemical Reagent Co., Ltd. (Shanghai China). Deionized (DI) water was used to prepare the chemicals. WT was collected from HP toner cartridges in printing shops from Yangzhou University.

\subsection{Preparation}

To prepare the magnetic nanomaterials in this study, WT was calcined in a tube furnace at $600{ }^{\circ} \mathrm{C}$ at a heating rate of $5{ }^{\circ} \mathrm{C} \mathrm{min}^{-1}$ for two hours in an atmosphere of air, vacuum, and ammonia. The material was then cooled to ambient temperature, and the finally prepared WTs denoted as WT(Air), WT(Vac), and WT $\left(\mathrm{NH}_{3}\right)$ were obtained by ball milling. Among them, the ammonia gas flow rate was $300-400 \mathrm{~mL} \mathrm{~min}^{-1}$. For comparison, the original WT without any treatment was also used in the experiments.

\subsection{Characterization}

The surface morphology of WTs was examined via scanning electron microscopy (SEM, S-4800II) and transmission electron microscopy (TEM, TF-20) coupled with energy dispersive X-ray spectroscopy (EDS, Vario EL cube). Brunauer-Emmett-Teller (BET) specific surface areas were measured using Micromeritics ASAP 2460. Elemental oxidation states and functional groups were determined via X-ray electron spectroscopy (XPS, ESCALAB 250Xi). The structure and phase of the as-prepared WTs were analyzed with an X-ray diffractometer (XRD, D8-ADVANCE).

\section{$2.4 \mathrm{Cr}(\mathrm{vI})$ removal experiments}

Batch experiments were performed to study the removal of $\mathrm{Cr}(\mathrm{vI})$ from aqueous solution using different WTs in $100 \mathrm{~mL}$ conical flasks containing $25 \mathrm{~mL}$ of solutions at the desired initial $\mathrm{Cr}(\mathrm{vI})$ concentrations and $\mathrm{pH}$ values. The most optimum dosage of WTs was determined by adding gradient concentrations ranging from 1 to $8 \mathrm{~g} \mathrm{~L}^{-1}$ during the experiment. The absorption and reduction of $\mathrm{Cr}(\mathrm{vI})\left(50 \mathrm{mg} \mathrm{L}^{-1}\right)$ by WTs were performed using $0.1 \mathrm{M} \mathrm{NaOH}$ and two different pH-regulating acids $\left(0.1 \mathrm{M} \mathrm{HCl}\right.$ and $\left.1.1 \mathrm{M} \mathrm{H}_{2} \mathrm{SO}_{4}\right)$ to adjust the $\mathrm{pH}$ value.

The mixture was placed on an Orbit shaker with continual mixing at $300 \mathrm{rpm}$. All experiments were carried out at the room temperature of $25{ }^{\circ} \mathrm{C}$ and were performed in duplicate. After reacting for a certain time, WTs were filtered through a $0.45 \mu \mathrm{m}$ membrane, and the residual $\mathrm{Cr}(\mathrm{vI})$ concentration was determined using an ultraviolet visible (UV) spectrophotometer at $\lambda$ $=540 \mathrm{~nm}$, according to the 1,5-diphenylcarbazide colorimetric method. ${ }^{36}$ To measure total $\mathrm{Cr}$ concentration, the 1,5-diphenylcarbazide colorimetric method (with $\mathrm{KMnO}_{4}$ ) was used. ${ }^{37}$ Also, the leached iron in the solution was determined using the 1,10-phenanthroline spectrophotometry method. ${ }^{38}$

\section{Results and discussion}

\subsection{Characteristics of as-prepared WTs}

Fig. 1 shows the XRD patterns of the original WT, WT(Air), WT(Vac) and WT( $\left.\mathrm{NH}_{3}\right)$. The diffraction peaks of the original WT at the $2 \theta$ values of $30.1^{\circ}, 35.58^{\circ}, 43.11^{\circ}, 53.45^{\circ}, 57.13^{\circ}$, and $62.59^{\circ}$ could be ascribed to the reflections of the (220), (311), (400), (422), (511), and (440) planes, respectively, which matched well with the standard pattern of JCPDS 019-0629 of the cubic lattice of $\mathrm{Fe}_{3} \mathrm{O}_{4}$. The characteristic peaks of $\mathrm{Fe}_{3} \mathrm{O}_{4}$ of WT(Air) and WT(Vac) were still observed. Based on the DebyeScherrer equation, the average crystallite size of $\mathrm{Fe}_{3} \mathrm{O}_{4}$ nanoparticles was calculated from the (311) plane, and it was found that the crystals were about $43.5 \mathrm{~nm}$ in diameter. ${ }^{39}$ Fig. 1(d) shows clear $\mathrm{Fe}_{2} \mathrm{~N}$ peaks, which are in accordance with PDF\#50$0958,{ }^{40}$ confirming that WT $\left(\mathrm{NH}_{3}\right)$ is an $\mathrm{Fe}_{3} \mathrm{O}_{4} / \mathrm{Fe}_{2} \mathrm{~N}$ nanohybrid. Furthermore, our results suggested that the chemical 


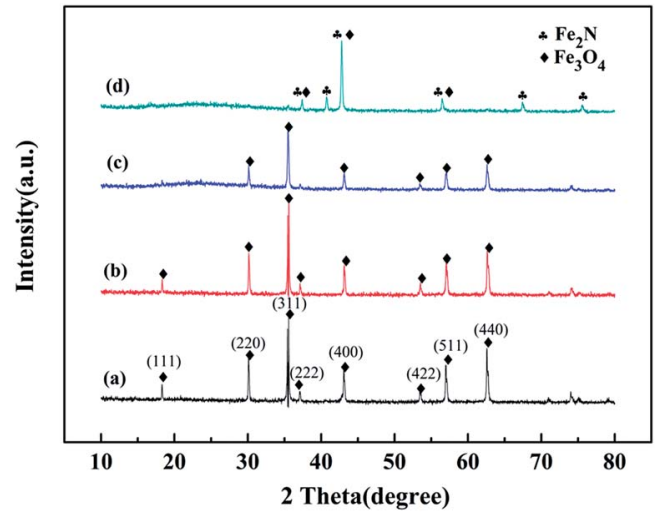

Fig. 1 XRD patterns of (a) original WT, (b) WT(Air), (c) WT(Vac), and (d) WT( $\left(\mathrm{NH}_{3}\right)$.

composition of the material can be changed by annealing at $600{ }^{\circ} \mathrm{C}$ in an ammonia atmosphere.

As shown in Fig. 2, compared with the result for the spectrum of original WT, the organic groups disappeared in the spectra of WT(Air), WT(Vac) and WT( $\left.\mathrm{NH}_{3}\right)$. The band at $578 \mathrm{~cm}^{-1}$ was related to the vibration of the $\mathrm{Fe}-\mathrm{O}$ functional group, which matched well with the characteristic peak of $\mathrm{Fe}_{3} \mathrm{O}_{4}{ }^{41}$ This finding was in accordance with the XRD patterns. The weak peaks between 1101 and $1151 \mathrm{~cm}^{-1}$ were assigned to the $\mathrm{Si}-\mathrm{O}-\mathrm{Si}$ group antisymmetric stretching vibration modes, indicating the existence of $\mathrm{SiO}_{2}$ in the material.

It can be seen from the SEM image (Fig. 3(a)) that original WT is a granular mixture with a diameter of about $5 \mu \mathrm{m}$. After calcination, $\mathrm{Fe}_{3} \mathrm{O}_{4}$ and $\mathrm{SiO}_{2}$ were retained in the residue. As shown in Fig. 3(b) and (c), WT(Vac) is found to be more aggregated than WT $\left(\mathrm{NH}_{3}\right)$, which was in accordance with the TEM results (Fig. 4(b)). The $\mathrm{Fe}_{3} \mathrm{O}_{4} / \mathrm{Fe}_{2} \mathrm{~N}$ nanoparticles displayed a spherical morphology with a mean diameter of $200 \mathrm{~nm}$ (Fig. 4(a)).

To further verify the distribution and structure of the material, TEM images of WT $\left(\mathrm{NH}_{3}\right)$ and $\mathrm{WT}(\mathrm{Vac})$ were obtained (Fig. 4). Both samples showed few tetragonal or spherical $\mathrm{Fe}_{2} \mathrm{~N}$ species, and spherical $\mathrm{Fe}_{3} \mathrm{O}_{4}$ species were also observed. Furthermore, WT $\left(\mathrm{NH}_{3}\right)$ had more phase interfaces of $\mathrm{Fe}_{3} \mathrm{O}_{4}$ and

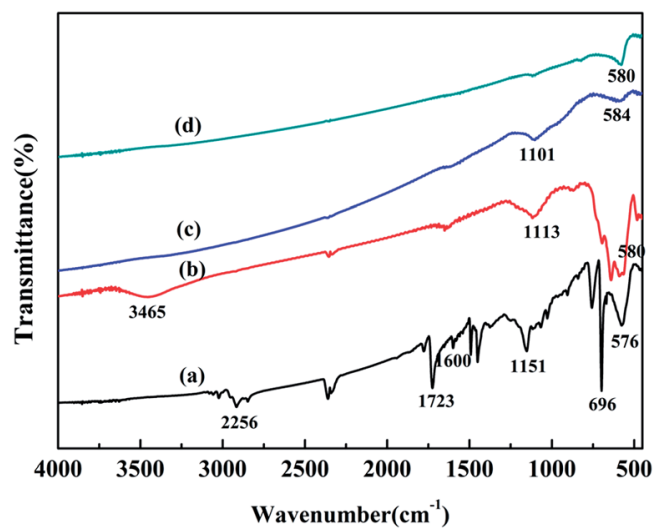

Fig. 2 FTIR spectra of (a) original WT, (b) WT(Air), (c) WT( $\left.\mathrm{NH}_{3}\right)$, and (d) WT(Vac).

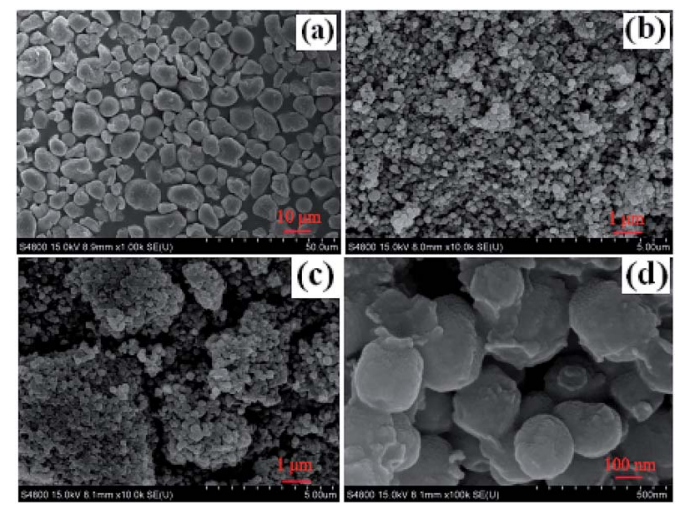

Fig. 3 SEM images of (a) original WT, (b) WT(NH $\mathrm{NH}_{3}$, (c) WT(Vac), and (d) WT $\left(\mathrm{NH}_{3}\right)$

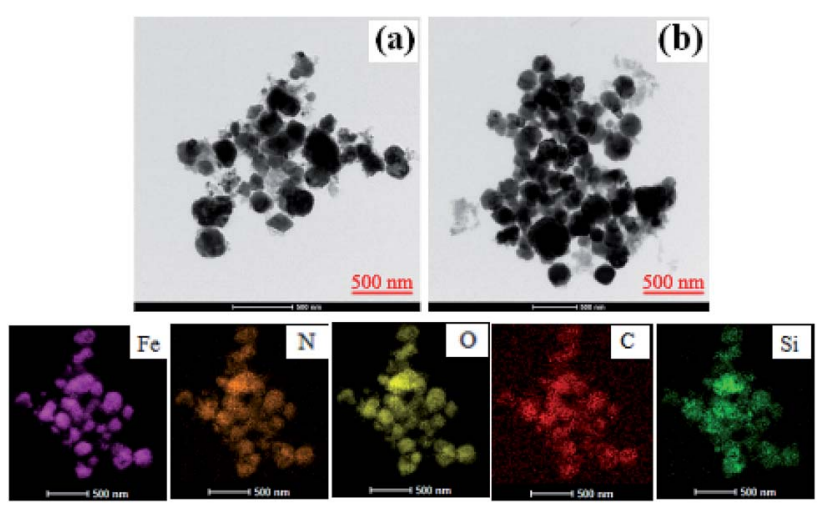

Fig. 4 TEM images of (a) WT $\left(\mathrm{NH}_{3}\right)$ and (b) WT(Vac) and the corresponding EDX elemental mappings of iron, nitrogen, oxygen, carbon, and silicon.

$\mathrm{Fe}_{2} \mathrm{~N}$ than WT(Vac). The EDS and TEM mapping analysis revealed the presence of $\mathrm{Fe}, \mathrm{Si}, \mathrm{C}$ and $\mathrm{O}$ in WTs and $\mathrm{Fe}, \mathrm{Si}, \mathrm{C}, \mathrm{N}$ and $\mathrm{O}$ in $\mathrm{WT}\left(\mathrm{NH}_{3}\right)$. Higher amount of $\mathrm{N}(8.6 \mathrm{wt} \%)$ was believed to be due to $\mathrm{N}$-doping from annealing in ammonia (Table 1).

The Brunauer-Emmett-Teller (BET) surface areas of WT(Air), WT(Vac) and WT( $\left.\mathrm{NH}_{3}\right)$ are shown in Table S1. $\dagger$ $\mathrm{WT}\left(\mathrm{NH}_{3}\right)$ has a larger surface area $\left(42.53 \mathrm{~m}^{2} \mathrm{~g}^{-1}\right)$ than WT(Vac) $\left(11.93 \mathrm{~m}^{2} \mathrm{~g}^{-1}\right)$ and WT(Air) $\left(11.75 \mathrm{~m}^{2} \mathrm{~g}^{-1}\right)$, which can improve mass transfer and increase the number of active sites. ${ }^{42}$ The pore volume is in good agreement with the surface area.

The XPS spectra of WT $\left(\mathrm{NH}_{3}\right)$ depicted in Fig. 5 exhibit the presence of $\mathrm{C}, \mathrm{O}, \mathrm{N}$, and Fe before the reaction. The $\mathrm{C} 1 \mathrm{~s}$ spectra exhibit four peaks; the peaks at binding energies of $284.7 \mathrm{eV}$ and

Table 1 Elemental compositions of the original WT, WT(Air), WT(Vac) and $\mathrm{WT}\left(\mathrm{NH}_{3}\right)(\%)$

\begin{tabular}{llrll}
\hline Sample & N & C & H & Fe \\
\hline WT & 0.049 & 52.66 & 5.232 & 32.07 \\
WT(Air) & 0.012 & 0.11 & 0.420 & 56.54 \\
WT(Vac) & 0.068 & 9.66 & 0.322 & 66.41 \\
WT( $\left.\mathrm{NH}_{3}\right)$ & 8.641 & 7.50 & 0.357 & 69.56
\end{tabular}



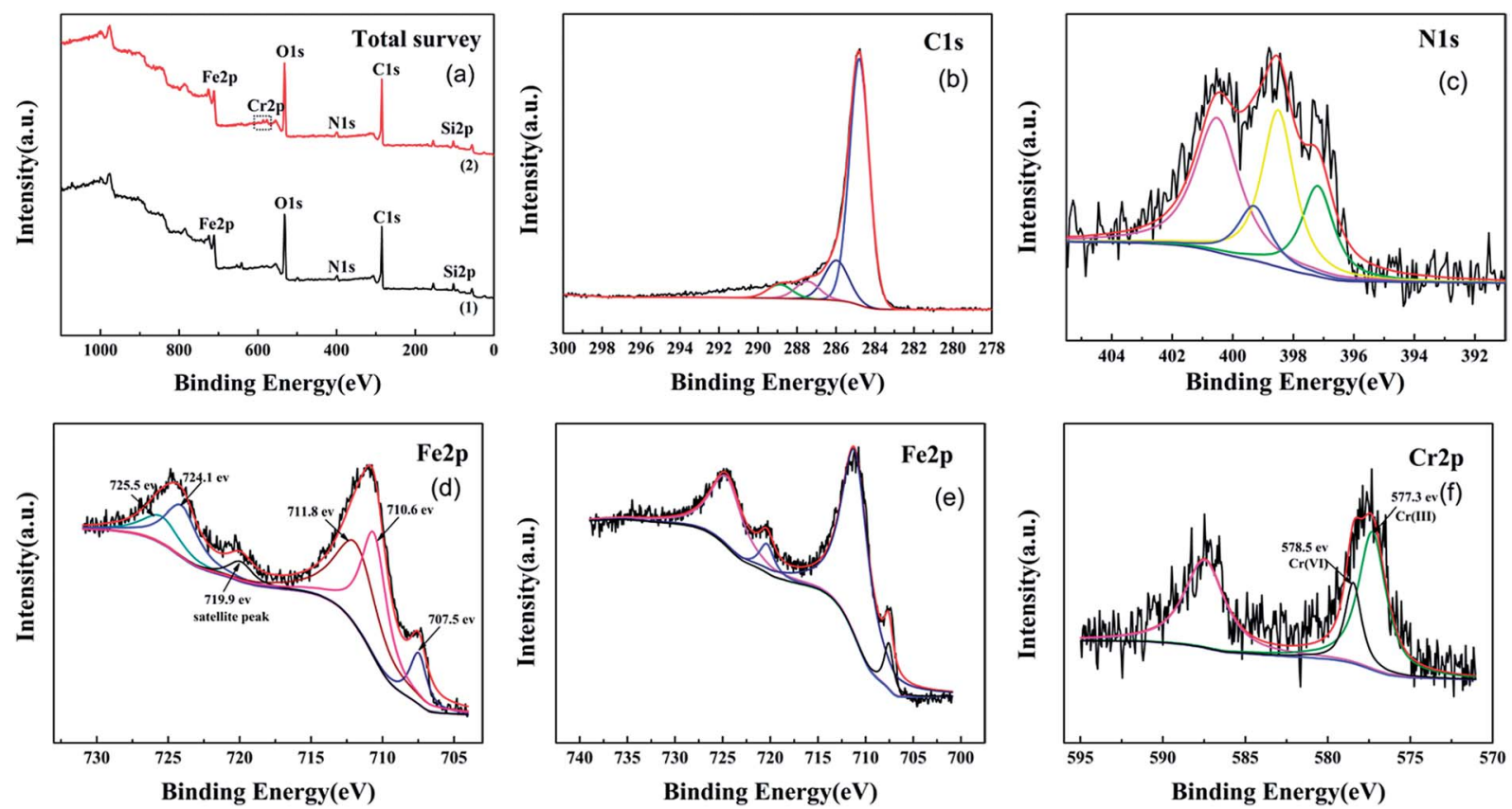

Fig. 5 XPS total survey (a), C 1s (b), N 1s (c), Cr-unloaded Fe 2p (d), Cr-loaded Fe 2p (e), and Cr 2p's (f) spectra.

$285.9 \mathrm{eV}$ corresponded to $\mathrm{C}-\mathrm{H}, \mathrm{C}-\mathrm{C}$, and hydroxyl $(\mathrm{C}-\mathrm{OH})$ bonds, and the peaks at $287.5 \mathrm{eV}(\mathrm{C}=\mathrm{O}, \mathrm{O}-\mathrm{C}-\mathrm{O})$ and $288.9 \mathrm{eV}$ corresponded to the carbonyl $(\mathrm{O}-\mathrm{C}=\mathrm{O})$ bond (Fig. 5(b)). ${ }^{43}$ Fig. 5(c) shows the high-resolution XPS spectra of the N peaks: pyrrolic- $\mathrm{N}$ at $400.5 \mathrm{eV}, \mathrm{Fe}-\mathrm{N}$ at $399.3 \mathrm{eV}$, and pyridinic- $\mathrm{N}$ at $398.6 \mathrm{eV} .^{44}$ Nitrogen was successfully doped into $\mathrm{Fe}_{3} \mathrm{O}_{4}$ and reacted with iron, which was consistent with $\mathrm{Fe}_{2} \mathrm{~N}$ from XRD characterization. The XPS Fe 2p spectra of WT $\left(\mathrm{NH}_{3}\right)$ showed two peaks centered at $710.9 \mathrm{eV}$ and $724.1 \mathrm{eV}$, which were assigned to $\mathrm{Fe} 2 \mathrm{p} 3 / 2$ and $\mathrm{Fe} 2 \mathrm{p} 1 / 2$, respectively. For $\mathrm{Fe} 2 \mathrm{p} 3 / 2$, the peak at $\mathrm{BE}$ of $710.6 \mathrm{eV}$ was assigned to ferrous iron in $\mathrm{Fe}_{3} \mathrm{O}_{4}\left(\mathrm{FeO} \cdot \mathrm{Fe}_{2} \mathrm{O}_{3}\right)$ and $\mathrm{Fe}_{2} \mathrm{~N}$, whereas that at $711.8 \mathrm{eV}$ corresponded to $\mathrm{Fe}(\mathrm{III})$ in $\mathrm{Fe}_{3} \mathrm{O}_{4}{ }^{45}$ Metallic iron was also observed at the binding energy of $707.5 \mathrm{eV}$ based on the Fe 2p3/2 spectra. The satellite peak at $719.9 \mathrm{eV}$ was much weaker, which further proved the absence of $\mathrm{Fe}_{3} \mathrm{O}_{4}$ rather than $\gamma-\mathrm{Fe}_{2} \mathrm{O}_{3} \cdot{ }^{46}$ These results were consistent with the TEM and XRD results.

The magnetization curves of original WT and WT $\left(\mathrm{NH}_{3}\right)$ were studied using a vibrating sample magnetometer (VSM) at an ambient temperature. The corresponding hysteresis loops are shown in Fig. 6, and the saturation magnetization of original WT was determined to be about $37.9 \mathrm{emu} \mathrm{g}^{-1}$, which decreased to $21.1 \mathrm{emu} \mathrm{g}^{-1}$ (WT( $\left(\mathrm{NH}_{3}\right)$ ) after calcination in an ammonia atmosphere. This can guarantee its convenient separation from pollutants when used as an adsorbent.

\subsection{Effect of sorbent on $\mathrm{Cr}(\mathrm{vI})$ removal}

To compare the $\mathrm{Cr}(\mathrm{vI})$ removal efficiencies of $\mathrm{WT}\left(\mathrm{NH}_{3}\right)$, WT(Vac), WT(Air) and original WT, the best reaction conditions were obtained: an initial $\mathrm{Cr}(\mathrm{vI})$ concentration of $50 \mathrm{mg} \mathrm{L}^{-1}$ and sorbent dosage of $4 \mathrm{~g} \mathrm{~L}^{-1}$ at $\mathrm{pH}=2.0$.

As shown in Fig. 7, $\mathrm{Cr}(\mathrm{vI})$ removal efficiencies decreased in the following order: $\mathrm{WT}\left(\mathrm{NH}_{3}\right)>\mathrm{WT}(\mathrm{Vac})>\mathrm{WT}($ Air $)>$ original

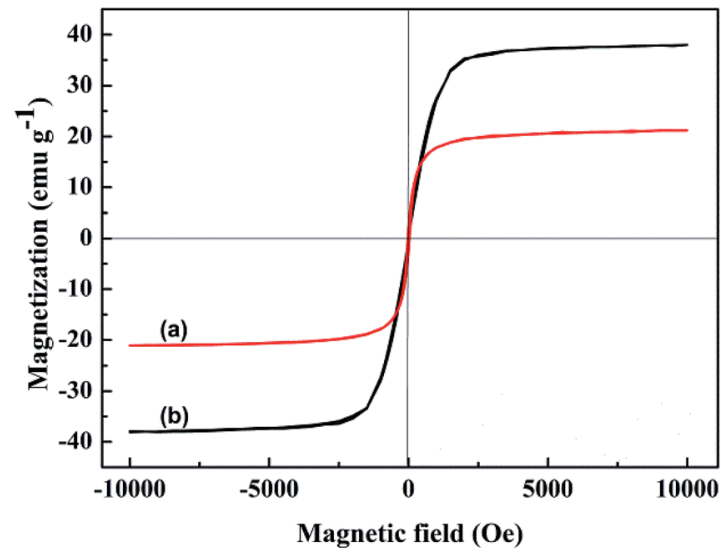

Fig. 6 Magnetic hysteresis loops of (a) original WT and (b) WT $\left(\mathrm{NH}_{3}\right)$.

WT. The effects of two pH-regulating acid $\left(\mathrm{HCl}\right.$ and $\left.\mathrm{H}_{2} \mathrm{SO}_{4}\right)$ treatments were investigated. Under $\mathrm{HCl}$ treatment, $\mathrm{WT}\left(\mathrm{NH}_{3}\right)$ removed $78.2 \%$ of $\mathrm{Cr}(\mathrm{vI})$ compared to $\mathrm{WT}(\mathrm{Vac})$ and $\mathrm{WT}(\mathrm{Air})$, which removed $29.9 \%$ and $5.3 \%$ of $\mathrm{Cr}(\mathrm{vI})$, respectively. Also, there was only a slight difference between WT(Vac) and WT(Air) under the two acid treatments. However, for $\mathrm{WT}\left(\mathrm{NH}_{3}\right)$, its $\mathrm{Cr}(\mathrm{vI})$ removal efficiency was greatly affected. Within the first $1.5 \mathrm{~h}$, its $\mathrm{Cr}(\mathrm{vI})$ removal efficiencies under $\mathrm{HCl}$ and $\mathrm{H}_{2} \mathrm{SO}_{4}$ treatments were almost identical. For $\mathrm{HCl}$ treatment, its efficiency showed only a gradually increasing trend after $2 \mathrm{~h}$; on the contrary, its efficiency increased sharply with $\mathrm{H}_{2} \mathrm{SO}_{4}$ treatment, which resulted in $99.9 \% \mathrm{Cr}(\mathrm{vI})$ removal after $7 \mathrm{~h}$.

\section{3 $\mathrm{Cr}$ (vi) removal kinetics and isotherms}

The pseudo-second-order kinetic model was used to determine the potential rate-limiting step involved in the $\mathrm{Cr}(\mathrm{vI})$ removal process by $\mathrm{WT}\left(\mathrm{NH}_{3}\right)$ and $\mathrm{WT}(\mathrm{Vac})$ (Fig. $\left.\mathrm{S} 1 \dagger\right)$. The kinetic 


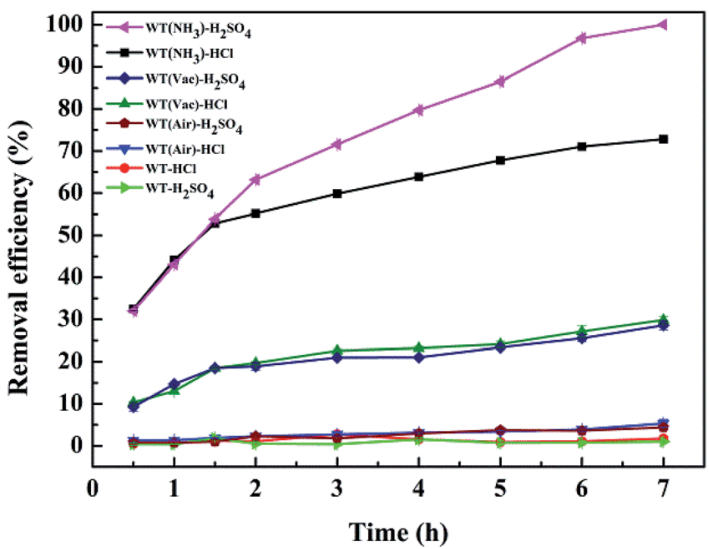

Fig. 7 Removal efficiency of $\mathrm{Cr}(\mathrm{vI})$ using different systems with reaction time. Reaction conditions: $4 \mathrm{~g} \mathrm{~L}^{-1}$ as-prepared sorbents, $49.68 \mathrm{mg} \mathrm{L}^{-1} \mathrm{Cr}(\mathrm{vI})$ concentration, and $\mathrm{pH}=2.0$.

parameters and $R^{2}$ were determined by linear regression (Table $\mathrm{S} 2 \dagger)$. The calculated $q_{\mathrm{e}}$ values of the pseudo-second-order kinetic model were close to the experimental data, indicating that the adsorption of $\mathrm{Cr}(\mathrm{vI})$ is mainly controlled by chemical adsorption. The $k$ value of WT(Vac) was higher than that of $\mathrm{WT}\left(\mathrm{NH}_{3}\right)$, which revealed that $\mathrm{WT}(\mathrm{Vac})$ exhibited faster adsorption of $\mathrm{Cr}(\mathrm{vI})$ and lower adsorption capacity than $\mathrm{WT}\left(\mathrm{NH}_{3}\right)$.

The linearized modeled isotherms are plotted in Fig. S2. $\dagger$ As shown, high correlation coefficients and good $R^{2}$ values were obtained from the isotherm models described for the removal of $\mathrm{Cr}(\mathrm{vI})$ by $\mathrm{WT}\left(\mathrm{NH}_{3}\right)$ in both $\mathrm{HCl}$ and $\mathrm{H}_{2} \mathrm{SO}_{4}$ systems (Table $\mathrm{S} 3 \dagger)$. The adsorption of $\mathrm{Cr}(\mathrm{vI})$ was well fitted by the Langmuir model than the Freundlich model, indicating that $\operatorname{Cr}(\mathrm{vI})$ removal by $\mathrm{WT}\left(\mathrm{NH}_{3}\right)$ is a monolayer adsorption process.

\subsection{Effect of initial $\mathrm{pH}$ on $\mathrm{Cr}(\mathrm{vI})$ removal}

The effect of initial pH on $\mathrm{Cr}(\mathrm{vI})$ removal by $\mathrm{WT}\left(\mathrm{NH}_{3}\right)$ was investigated, and it was shown that the $\operatorname{Cr}(\mathrm{vI})$ adsorption is strongly dependent on the values of solution pH (Fig. 8). It can

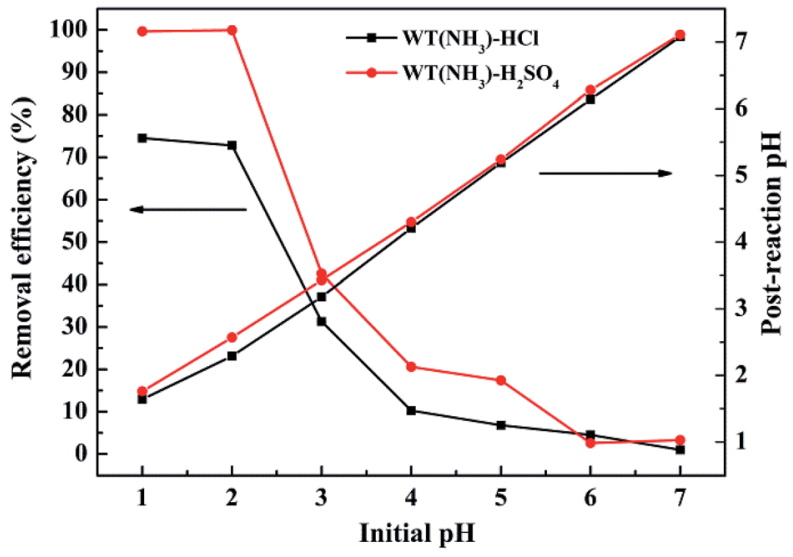

Fig. 8 Effect of initial pH on $\mathrm{Cr}(\mathrm{VI})$ removal efficiency by $\mathrm{WT}\left(\mathrm{NH}_{3}\right)$ Reaction conditions: $4 \mathrm{~g} \mathrm{~L}^{-1} \mathrm{WT}\left(\mathrm{NH}_{3}\right), 49.68 \mathrm{mg} \mathrm{L}^{-1} \mathrm{Cr}(\mathrm{VI})$ concentration, and $7 \mathrm{~h}$ reaction time. be clearly observed that the removal efficiency of $\mathrm{Cr}(\mathrm{vI})$ decreased with an increase in the solution $\mathrm{pH}$ value. Specifically, the $\mathrm{Cr}(\mathrm{vI})$ removal efficiencies were $78.2 \%$ and $99.9 \%$ in the $\mathrm{HCl}$ and $\mathrm{H}_{2} \mathrm{SO}_{4}$ systems, respectively, at $\mathrm{pH}$ 2, and these values dropped sharply with an increase in $\mathrm{pH}$ to 3 . Also, the $\mathrm{pH}$ increased after the reaction, which was possibly due to the consumption of $\mathrm{H}^{+}$during the reduction of $\mathrm{HCrO}_{4}{ }^{-}$and $\mathrm{Cr}_{2} \mathrm{O}_{7}{ }^{2-}$ to $\mathrm{Cr}(\mathrm{III}) .^{47,48}$ At neutral $\mathrm{pH}$, only $0.4-0.8 \% \mathrm{Cr}(\mathrm{VI})$ was removed in the $\mathrm{HCl}$ and $\mathrm{H}_{2} \mathrm{SO}_{4}$ systems. With an increase in $\mathrm{pH}$, the formation of $\mathrm{Cr}(\mathrm{VI})$ or $\mathrm{Cr}(\mathrm{III})$ precipitates was enhanced, which blocked the reactive sites. ${ }^{49}$

To investigate the surface charge of $\mathrm{WT}\left(\mathrm{NH}_{3}\right)$, we measured its zeta potential (Fig. S3 $\dagger$ ). The isoelectric point of $\mathrm{WT}\left(\mathrm{NH}_{3}\right)$ was found to be about $\mathrm{pH} 2$. Below this value, the surface of WT $\left(\mathrm{NH}_{3}\right)$ was positively charged, which was beneficial to bind with chromium anions through electrostatic attraction and ion exchange. At high $\mathrm{pH}$ values, the surface of $\mathrm{WT}\left(\mathrm{NH}_{3}\right)$ became less positively charged, which might be unfavourable for $\mathrm{Cr}(\mathrm{vI})$ adsorption. ${ }^{50}$

\section{5 $\mathrm{Cr}(\mathrm{vi})$ removal mechanisms}

To investigate the $\mathrm{Cr}(\mathrm{vI})$ removal mechanism of WTs, both the XPS and EDS techniques were used to characterize the surface chemical composition of $\mathrm{WT}\left(\mathrm{NH}_{3}\right)$ before and after the reaction. After the reaction, some new peaks appeared, which coincided with those in the photoelectron spectra of $\mathrm{Cr} 2 \mathrm{p}$. High resolution XPS spectra were used to clarify the state of $\mathrm{Cr}$ absorbed on the surface of $\mathrm{WT}\left(\mathrm{NH}_{3}\right)$, and the results are shown in Fig. 5(f). The Cr 2p spectra exhibited two peaks, namely, $\mathrm{Cr}$ 2p3/2 (577.6 eV) and Cr 2p1/2 (587.5 eV). Using XPS-peakdifferentiating analysis, the $\mathrm{Cr} 2 \mathrm{p} 3 / 2$ spectra were deconvoluted into two major components at binding energies of $578.5 \mathrm{eV}$ and $577.3 \mathrm{eV}$, which were due to $\mathrm{Cr}(\mathrm{VI})$ and $\operatorname{Cr}(\mathrm{III})$, respectively. ${ }^{51}$ This demonstrated the coexistence of both $\mathrm{Cr}(\mathrm{vI})$ and $\mathrm{Cr}(\mathrm{III})$ on the surface of $\mathrm{WT}\left(\mathrm{NH}_{3}\right)$ after reacting with $\mathrm{Cr}(\mathrm{VI})$, indicating that the $\mathrm{Fe}_{3} \mathrm{O}_{4} / \mathrm{Fe}_{2} \mathrm{~N}$ nanocomposite in $\mathrm{WT}\left(\mathrm{NH}_{3}\right)$ is beneficial for the reduction of $\operatorname{Cr}(\mathrm{vI})$ to $\mathrm{Cr}(\mathrm{III})$. Moreover, the splitting of $\mathrm{Cr} 2 \mathrm{p} 3 / 2$ line peak into two peaks indicated the precipitation of $\mathrm{Cr}_{2} \mathrm{O}_{3}$ or $\mathrm{Cr}(\mathrm{OH})_{3}$ during the adsorption process. ${ }^{52}$ Based on the analysis, the ratio of $\mathrm{Cr}(\mathrm{III}) / \mathrm{Cr}(\mathrm{VI})$ was found to be $2.8: 1$, implying that the reaction mechanisms might be sorption together with reduction processes. In addition, the concentrations of total $\mathrm{Cr}$ decreased by $14 \%$ and $46 \%$ in the $\mathrm{H}_{2} \mathrm{SO}_{4}$ and $\mathrm{HCl}$ systems, respectively. All the $\mathrm{Cr}(\mathrm{vI})$ ions were almost reduced to $\mathrm{Cr}(\mathrm{III})$ in the solution; thus, the $\mathrm{H}_{2} \mathrm{SO}_{4}$ system can promote the reduction of $\mathrm{Cr}(\mathrm{vI})$ by $\mathrm{WT}\left(\mathrm{NH}_{3}\right)$ (Fig. S4(b) $\dagger$ ).

As shown in Fig. 5(e), the binding energies of Fe 2p after $\mathrm{Cr}$ adsorption at $724.6 \mathrm{eV}, 720.4 \mathrm{eV}$, and $711.1 \mathrm{eV}$ may be assigned to $\mathrm{Fe}(\mathrm{III})$, suggesting that $\mathrm{Fe}(\mathrm{II})$ on the surface of the material was oxidized to $\mathrm{Fe}(\mathrm{III})$ during the redox process. Hence, lower $\mathrm{pH}$ facilitated the transformation of $\mathrm{Fe}(\mathrm{III})$ to $\mathrm{Fe}(\mathrm{II})$ during the adsorption process. The measurements of the concentration of $\mathrm{Fe}(\mathrm{II})$ were performed in acidic solution $(\mathrm{pH}=2)$ during the reaction (Fig. $\mathrm{S} 4(\mathrm{a}) \dagger$ ). Under $\mathrm{H}_{2} \mathrm{SO}_{4}$ treatment, the content of $\mathrm{Fe}(\mathrm{II})$ was considerably higher than that under $\mathrm{HCl}$ treatment 
with and without $\mathrm{Cr}(\mathrm{vI})$, and the results showed that the content of $\mathrm{Fe}$ (II) ions reached about $108.3 \mathrm{mg} \mathrm{L}^{-1}$ with no $\mathrm{Cr}$ (VI) in the $\mathrm{H}_{2} \mathrm{SO}_{4}$ system. When $\mathrm{Cr}(\mathrm{vI})$ was added, the concentration of $\mathrm{Fe}(\mathrm{II})$ ions decreased to about $9.24 \mathrm{mg} \mathrm{L}^{-1}$ in $7 \mathrm{~h}$.

These interesting findings indicate that $\mathrm{Fe}_{3} \mathrm{O}_{4} / \mathrm{Fe}_{2} \mathrm{~N}$ may have high reduction activity and can release a large amount of $\mathrm{Fe}(\mathrm{II})$ under $\mathrm{H}_{2} \mathrm{SO}_{4}$ treatment. As shown in Fig. 7, $\mathrm{Fe}_{3} \mathrm{O}_{4}$ alone has no effect on activation in the $\mathrm{H}_{2} \mathrm{SO}_{4}$ system. Also, both $\mathrm{Fe}_{3} \mathrm{O}_{4}$ and $\mathrm{Fe}_{2} \mathrm{~N}$ are inefficient in reducing $\mathrm{Cr}(\mathrm{vI})$ in the $\mathrm{HCl}$ system. Therefore, this suggests that the high efficiency of $\mathrm{WT}\left(\mathrm{NH}_{3}\right)$ is due to the active sites at the interface of the two phases of $\mathrm{Fe}_{2} \mathrm{~N}$ and $\mathrm{Fe}_{3} \mathrm{O}_{4}$ or $\mathrm{Fe}_{2} \mathrm{~N}$ itself; ${ }^{53}$ this is consistent with the TEM results, showing that WT $\left(\mathrm{NH}_{3}\right)$ has much more $\mathrm{Fe}_{3} \mathrm{O}_{4}$ and $\mathrm{Fe}_{2} \mathrm{~N}$ interfaces.

According to the above-mentioned analysis and discussion, a possible mechanism for $\mathrm{Cr}(\mathrm{vI})$ removal by $\mathrm{WT}\left(\mathrm{NH}_{3}\right)$ is proposed (Fig. 9). First, $\mathrm{Cr}(\mathrm{vI})$ was partly absorbed by $\mathrm{WT}\left(\mathrm{NH}_{3}\right)$ in both the $\mathrm{HCl}$ and $\mathrm{H}_{2} \mathrm{SO}_{4}$ systems. Second, WT( $\left.\mathrm{NH}_{3}\right)$ released both $\mathrm{Fe}(\mathrm{III})$ and $\mathrm{Fe}(\mathrm{II})$. Meanwhile, some Fe(III) ions were converted to $\mathrm{Fe}$ (II) at a very low $\mathrm{pH}$ value. Third, the $\mathrm{Cr}$ (vI) ions were reduced to $\mathrm{Cr}(\mathrm{III})$ by $\mathrm{Fe}(\mathrm{II})$ (eqn (1)), ${ }^{31}$ which explained the presence of $\mathrm{Cr}$ (III) species in both the aqueous solution and on the surface of $\mathrm{WT}\left(\mathrm{NH}_{3}\right)$. This was also supported by the decrease in the concentration of $\mathrm{Fe}$ (II) in the solution with $\mathrm{Cr}$ (VI). In addition, $\mathrm{SO}_{4}{ }^{2-}$ could activate $\mathrm{Fe}_{2} \mathrm{~N}$ or the interface of $\mathrm{Fe}_{2} \mathrm{~N}$ and $\mathrm{Fe}_{3} \mathrm{O}_{4}$ and thus, it could accelerate the release of ferrous ions.

$$
3 \mathrm{Fe}^{2+}+\mathrm{CrO}_{4}^{2-}+4 \mathrm{H}_{2} \mathrm{O} \rightarrow 3 \mathrm{Fe}^{3+}+\mathrm{Cr}^{3+}+8 \mathrm{OH}^{-}
$$

From the above-mentioned results, waste toner can be utilized to prepare functional nanomaterials under different conditions. As indicated in this study, the good sorptive and reductive capacities for $\mathrm{CrO}_{4}{ }^{2-}$ are ascribed to the active sites and $\mathrm{Fe}_{3} \mathrm{O}_{4}$ and $\mathrm{Fe}_{2} \mathrm{~N}$ in the nanocomposites. Since functional magnetic $\mathrm{Fe}_{3} \mathrm{O}_{4}$ shows good affinity for many heavy metals such as lead, ${ }^{54}$ arsenic ${ }^{55}$ and copper, ${ }^{56}$ the as-prepared toner-based sorbents can be used to remove a wide spectrum of heavy metals. Besides, the sorbents can be used to remediate wastewater contaminated by pharmaceuticals and other organic pollutants because $\mathrm{Fe}_{2} \mathrm{~N}$ may promote catalytic degradation of organic compounds. ${ }^{53,57}$ Thus, waste toner can be potentially used for the removal of heavy metals and organic contaminants.

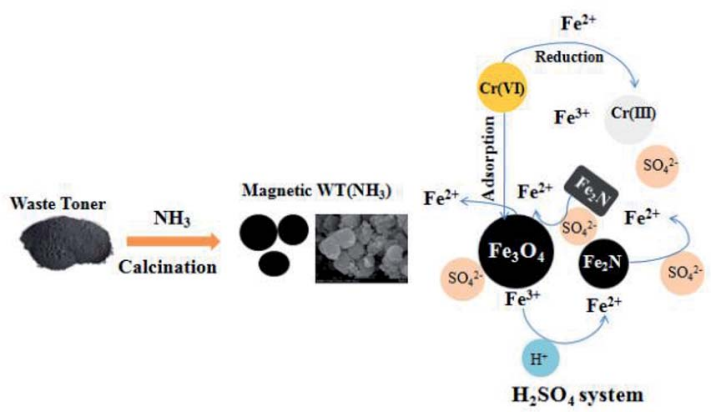

Fig. 9 Preparation route for magnetic WT( $\left(\mathrm{NH}_{3}\right)$ and its mechanism for $\mathrm{Cr}(\mathrm{VI})$ removal in the $\mathrm{H}_{2} \mathrm{SO}_{4}$ system.

\section{Conclusions}

In this study, we prepared a novel magnetic nanocomposite using waste toner through high-temperature decomposition. The XRD analysis confirmed the existence of $\mathrm{Fe}_{3} \mathrm{O}_{4}$ and $\mathrm{Fe}_{2} \mathrm{~N}$ nanoparticles in $\mathrm{WT}\left(\mathrm{NH}_{3}\right)$. $\mathrm{Cr}(\mathrm{vI})$ adsorption properties and magnetism characteristics of $\mathrm{WT}\left(\mathrm{NH}_{3}\right)$ were investigated. WT $\left(\mathrm{NH}_{3}\right)$ exhibited high magnetization and good dispersibility. The enhanced efficiency for the removal of $\mathrm{Cr}(\mathrm{vI})$ can be related to its higher surface area and existence of $\mathrm{Fe}_{2} \mathrm{~N}$. In fact, TEM results revealed that $\mathrm{WT}\left(\mathrm{NH}_{3}\right)$ has more $\mathrm{Fe}_{2} \mathrm{~N}$ and $\mathrm{Fe}_{3} \mathrm{O}_{4}$ interfaces. The XPS analysis indicated that $\mathrm{Cr}(\mathrm{vI})$ was partly reduced to $\mathrm{Cr}$ (III) by $\mathrm{Fe}(\mathrm{II})$ during the process. Batch sorption experiments indicated that using $\mathrm{H}_{2} \mathrm{SO}_{4}$ to adjust $\mathrm{pH}$ could effectively help release a large amount of $\mathrm{Fe}(\mathrm{II})$ to reduce toxic $\mathrm{Cr}(\mathrm{VI})$ by WT $\left(\mathrm{NH}_{3}\right)$. Our study suggests that the facilely synthesized sorbent is efficient for the removal of $\mathrm{Cr}(\mathrm{vI})$ for environmental applications.

\section{Conflicts of interest}

There are no conflicts to declare.

\section{Acknowledgements}

This work was financially supported by the Qing Lan Project, the National Science Foundation of China (31772394, 51602281), Social development project of Jiangsu Province (BE2015661), Six-talent peaks project in Jiangsu Province (2013-NY-017). We thank the Testing Center of Yangzhou University for Sample Characterization.

\section{References}

1 J. O. Nriagu and E. Nieboer, J. Ecol., 1988, 71, 1.

2 A. Broadway, M. R. Cave, J. Wragg, F. M. Fordyce, R. J. F. Bewley, M. C. Graham, B. T. Ngwenya and J. G. Farmer, Sci. Total Environ., 2010, 409, 267-277.

3 Y. T. Wang, E. M. Chirwa and H. Shen, J. Environ. Eng., 2000, 126, 300-306.

4 Agency, E. P. U. S, Drinking Water Regulations and Health Advisories, May 1995.

5 M. Dakiky, M. Khamis, A. Manassra and M. Mer'Eb, Adv. Environ. Res., 2002, 6, 533-540.

6 J. Kotaś and Z. Stasicka, Environ. Pollut., 2000, 107, 263-283.

7 M. K. Dinker and P. S. Kulkarni, ChemInform, 2015, 60, 25212540.

8 E. A. Schmieman, J. N. Petersen, D. R. Yonge, D. L. Johnstone, Y. Bereded-Samuel, W. A. Apel and C. E. Turick, Appl. Biochem. Biotechnol., 1997, 63, 855-864.

9 A. E. Pagana and S. D. Sklari, J. Membr. Sci., 2011, 367, 319324.

10 R. L. Goswamee, P. Sengupta, K. G. Bhattacharyya and D. K. Dutta, Appl. Clay Sci., 1998, 13, 21-34.

11 T. Ölmez, J. Hazard. Mater., 2009, 162, 1371-1378.

12 K. P. Singh, A. K. Singh, S. Gupta and S. Sinha, Desalination, 2011, 270, 275-284. 
13 Y. F. Kong, Y. C. Li, G. S. Hu, N. Cao, Y. Q. Ling, D. Pan, Q. Shao and Z. H. Guo, Polym. Adv. Technol., 2018, 1-8.

14 Y. F. Kong, Y. C. Li, G. S. Hu, J. Lin, D. Pan, D. Y. Dong, E. Wujick, Q. Shao, M. J. Wu, J. Z. Zhao and Z. H. Guo, Polymer, 2018, 145, 232-241.

15 H. J. Kang, Q. Shao, X. K. Guo, A. Galaska, Y. Y. Liu and Z. H. Guo, Eng. Sci., 2018, 1, 78-85.

16 J. Zheng, J. Ruan, L. Dong, T. Zhang, M. Huang and Z. Xu, ACS Sustainable Chem. Eng., 2016, 5, 161-167.

17 J. Ruan, J. Li and Z. Xu, J. Hazard. Mater., 2011, 185, 696-702.

18 J. Ruan, J. Li and Z. Xu, Environ. Sci. Technol., 2013, 47, 64576462.

19 J. Ruan, L. Dong, J. Huang, Z. Huang, K. Huang and H. Dong, ACS Sustainable Chem. Eng., 2017, 5, 4923-4929.

20 J. Ruan and Z. Xu, Environ. Sci. Technol., 2012, 46, 6214.

21 V. Gaikwad, U. Kumar, F. Pahlevani, A. Piadasa and V. Sahajwalla, ACS Sustainable Chem. Eng., 2017, 5, 1154311550.

22 H. H. Hu, H. P. Liu, D. J. Zhang, J. J. Wang, G. W. Qin and X. F. Zhang, Eng. Sci., 2018, 2, 43-48.

23 H. K. Wu, Y. Zhang, R. Yin, W. Zhao, X. M. Li and L. Qian, Adv. Compos Hybrid. Mater., 2018, 1, 168-176.

24 Y. X. He, S. Yang, H. Liu, Q. Shao, Q. Y. Chen, C. Lu, Y. L. Jiang, C. T. Liu and Z. H. Guo, J. Colloid Interface Sci., 2018, 517, 40-51.

25 M. L. Peterson, A. F. White, G. E. Brown and G. A. Parks, Environ. Sci. Technol., 1997, 31, 1573-1576.

26 T. Kendelewicz, P. Liu, C. S. Doyle, G. E. Brown Jr, E. J. Nelson and S. A. Chambers, Surf. Sci., 1999, 424, 219231.

27 Y. Gong, L. Gai, J. Tang, J. Fu, Q. Wang and E. Y. Zeng, Sci. Total Environ., 2017, 595, 743-751.

28 J. Pan, J. Jiang and R. K. Xu, Chemosphere, 2014, 101, 71-76.

29 U. Schwertmann, U. Gasser and H. Sticher, Geochim. Cosmochim. Acta, 1989, 53, 1293-1297.

30 B. A. Manning, J. R. Kiser, H. Kwon and S. R. Kanel, Environ. Sci. Technol., 2007, 41, 586-592.

31 B. Qiu, H. B. Gu, X. R Yan, J. Guo, Y. R. Wang, D. Z. Sun, Q. Wang, M. Khan, X. Zhang, B. L. Weeks, D. P. Young, Z. H. Guo and S. Y. Wei, J. Mater. Chem. A, 2014, 2, 1745417462.

32 J. H. Zhu, H. B. Gu, J. Guo, M. J. Chen, H. G. Wei, Z. P. Luo, H. A. Colorado, N. Yerra, D. W. Ding, T. C. Ho, N. Haldolaarachchige, J. Hopper, D. P. Young, Z. H. Guo and S. Y. Wei, J. Mater. Chem. A, 2014, 2, 2256-2265.

33 J. N. Huang, Y. H. Cao, Q. Shao, X. F. Peng and Z. H. Guo, Ind. Eng. Chem. Res., 2017, 56, 10689-10701.
34 B. Qiu, Y. R. Wang, D. Z. Sun, Q. Wang, X. Zhang, B. L. Weeks, R. O'Connor, X. H. Huang, S. Y. Wei and Z. H. Guo, J. Mater. Chem. A, 2015, 3, 9817-9825.

35 G. Liu, Q. Deng, H. Wang, S. Kang, Y. Yang and D. H. L. Ng, Chem.-Eur. J., 2012, 18, 13418-13426.

36 S. C. Ponce, C. Prado, E. Pagano, F. E. Prado and M. Rosa, Ecol. Eng., 2015, 74, 33-41.

37 Q. Wang, X. Chen, K. Yu, Y. Zhang and Y. Cong, J. Hazard. Mater., 2013, 246-247, 135-144.

38 D. S. Sigman, Acc. Chem. Res., 1989, 19, 13-27.

39 A. Mirmohseni, M. S. S. Dorraji and M. G. Hosseini, Electrochim. Acta, 2012, 70, 182-192.

40 X. Huang, Z. Yang, B. Dong, Y. Wang, T. Tang and Y. Hou, Nanoscale, 2017, 9, 8102-8106.

41 L. Guo, P. Ye, J. Wang, F. Fu and Z. Wu, J. Hazard. Mater., 2015, 298, 28-35.

42 H. W. Liang, X. Zhuang, S. Brüller, X. Feng and K. Müllen, Nat. Commun., 2014, 5, 4973.

43 Z. Yue, S. E. Bender, J. Wang and J. Economy, J. Hazard. Mater., 2009, 166, 74-78.

44 L. Lin, Q. Zhu and A. W. Xu, J. Am. Chem. Soc., 2014, 136, 11027-11033.

45 D. Wilson and M. A. Langell, Appl. Surf. Sci., 2014, 303, 6-13. 46 Y. Tian, B. B. Yu, X. Li and K. Li, J. Mater. Chem., 2011, 21, 2476-2481.

47 F. Gao, H. Gu, H. Wang, X. Wang, B. Xiang and Z. Guo, RSC $A d v .$, 2015, 5, 60208-60219.

48 S. Shi, J. Yang, S. Liang, M. Li, Q. Gan and K. Xiao, Sci. Total Environ., 2018, 628-629, 499-508.

49 T. Papadam, N. P. Xekoukoulotakis, I. Poulios and D. Mantzavinos, J. Photochem. Photobiol., A, 2007, 186, 308315.

50 J. Jiang, Q. Cai, W. Xu, M. W. Yang, Y. Cai, D. D. Dionysiou and K. E. O'Shea, Environ. Sci. Technol., 2014, 48, 8078-8085.

51 X. Tian, W. Wang, T. Na, C. Zhou, Y. Chao and S. Komarneni, J. Hazard. Mater., 2016, 309, 151-156.

52 Z. Ai, Y. Cheng, L. Zhang and J. Qiu, Environ. Sci. Technol., 2008, 42, 6955-6960.

53 J. Wang, C. Wang, S. Tong, J. Wang, C. Wang and S. Tong, Catal. Commun., 2017, 103, 105-109.

54 L. Tan, J. Xu, X. Xue, Z. Lou, J. Zhu and S. A. Baig, RSC Adv., 2014, 4, 45920-45929.

55 L. Y. Feng, M. H. Cao, X. Y. Ma, Y. S. Zhu and C. W. Hu, J. Hazard. Mater., 2012, 217, 439-446.

56 H. B. Hu, Z. H. Wang and L. J. Pan, J. Alloys Compd., 2010, 492, 656-661.

57 N. Zhang, H. Zhao, G. M. Zhang, S. Chong, Y. C. Liu, L. Y. Sun, H. Z. Chang and T. Huang, J. Environ. Manage., 2017, 187, 201-211. 